\title{
Problems Mudharabah Mutlaqah in Muamalat Bank Jambi Branch (Study Between Theory and Practice)
}

\author{
Muhammad Qodri \\ \{muhammad.9odri18@yahoo.com\} \\ Jambi University, Indonesia
}

\begin{abstract}
The more advanced a country is, the greater the role of banks in controlling the country. This means that the existence of the banking world is increasingly needed by the government and society. Financial institutions are really needed by the government and society, because banks help a lot of business smoothly, especially in meeting the needs of life. So important is the world of banking, so that there is an assumption that banks are the lives to drive the economy of a country. Mudharabah mutlaqah is a contract of cooperation between two parties or more to finance a halal type of business, where the specifications of business type, time, and business area are not limited by shohibul maal. If the business experiences profit, it will be divided according to the agreed agreement and if the business experiences a loss, the loss will be borne by both parties. but it is different from the aspect of mudharabah mutlaqah practice applied by the Bank Muamalat Indonesia Jambi Branch, if the type of business managed by mudarib suffers a loss, then the mudharib must pay regularly every month.
\end{abstract}

Keywords: Mudharabah Mutlaqah Product, Bank, and Community

\section{Introduction}

In today's modern world, banking has a very important role in every country's economic activities. Banks can be said to be the blood of a country's economy. Therefore the progress of a bank in a country can also be used as a measure of the progress of the country concerned. The more advanced a country is, the greater the role of banks in controlling the country. This means that the existence of the banking world is increasingly needed by the government and society. Financial institutions are really needed by the government and society, because banks help a lot of business smoothly, especially in meeting the needs of life. So important is the world of banking, so that there is an assumption that banks are the lives to drive the economy of a country.

This assumption is certainly not wrong, because the function of banks as financial institutions is very vital, for example in terms of money creation, circulating money, menstruating money, providing financing to support business activities, places to secure money, investment places and other financial services.

The bank is a financial intermediary institution or the so-called financial intermediary, meaning that the bank is an institution whose activities are related to financial problems which are also a means of facilitating the occurrence of major trade.

According to (Antonio, 2010) and (Atmaja, 2008) Officers "Syari'ah Bank is a bank that operates in accordance with the principles of Islamic Shari'ah and the procedure for its operation refers to the provisions of the Qur'an and Hadith.

The rapid development of Syari'ah banking certainly determines adequate human resources and has competence in the Shariah banking sector. In order for this development to 
be carried out effectively and optimally, the human resources, especially marketing officers who are the foremost actors in the operations of Bank Syari'ah, need to understand correctly the concept of Shariah banking.

Among the products offered by Bank Syari'ah are mudharabah products. Mudharabah or qiradh is one form of syirkah contract or partnership. The term mudharabah is used by Iraqis, while Hijaz people call it the term qiradh. Thus, mudaraba and qiradh are two terms for the same purpose. Mudharabah is a financing transaction involving two or more parties where the first party owns and has capital (shohibul maal) to finance a type of business that is lawful, and the second party runs a type of business to be managed by mudarib.

Mudharabah is usually applied to collecting and financing products.

a. On collection products

- Time savings, which are savings intended for special purposes, such as Hajj savings, and sacrificial savings.

- Special deposits, where funds deposited by customers are specific to certain businesses, such as murabahah or ijarah

b. On financing products

- Working capital financing, such as trade and service working capital.

- Special investment is also called mudharabah muqayyadah, where special funding sources with special distribution with the conditions set by Shohibul Maal.

When viewed from its type, mudaraba can be divided into two, namely mudharabah mutlaqah and mudharabah muqayyadah. In Shariah banking practices in Indonesia, the principle fund collection products used are mudharabah muthlaqah while mudharabah muqayyadah is more often used in service products whose application to Syari'ah Bank is a special investment product that is a project directly financed by the customer.

Mudharabah muqayyadah or also referred to as restricted mudaraba or specified mudaraba is mudharib restricted by the limitation of type of business, time, or place of business. This limitation often reflects the general tendency of the shohibul maal to enter the business world.

At Muamalat bank Jambi Branch, mudharabah muqayyadah is a contract of cooperation between two or more parties to finance a halal business, where the specifications of business type, time, and business area are limited by shohibu maal. With the agreement the profit is divided between the two parties in accordance with the agreement, while the loss is borne by Shohibul Maal, unless the loss is as a result of the manager's fault (mudharib).

Mudharabah mutlaqah can be interpreted as a contract of cooperation between two parties or more to finance a halal type of business, if the business experiences a profit it will be divided according to the agreed agreement and if the business experiences a loss, then the loss will be borne by both parties party.

This is in line with Profit Sharing, or the principle of profit sharing which is a general characteristic and basic foundation for the operation of Islamic banks as a whole. In Syri'ah, the principle is based on the mudharbah rule. While the risk that will arise is simply not getting the profit sharing or borne by both parties.

Profit or loss recognition in practice can be known based on the profit sharing report from the fund manager received by the bank. In this case the loss incurred is recognized in the period of the loss and can reduce the mudharabah financing balance.

But it is different from what I see in terms of mudharabah mutlaqah practices that are applied by the Mandiri Syariah Bank Branch Jambi, if the type of business managed by mudarib suffers a loss, then the mudharib must pay regularly every month. From here I see a 
difference between the theory and practice applied by the Muamalat Indonesia Bank Jambi Branch to its customers.

The strengths and weaknesses of the mudharabah system are:

a) Strength (strength) of the mudharabah system, namely:

- There is support from Muslims who constitute the majority of the population, because mudaraba is one of the products that has long been the desire of Muslims in Indonesia. This shows the amount of hope and support of Muslims towards the mudaraba system itself.

- Support from Islamic financial institutions around the world. Because with the existence of a mudaraba system that is in accordance with the principles of Islamic shari'ah, it is very important to avoid the Muslims from the possibility of falling prey to the illegitimate. Therefore at the second conference of foreign ministers of Muslim countries around the world in December 1970 in Karachi, Pakistan agreed to the first stage of establishing the Islamic Development Bank (IDB) whose operations are in accordance with Islamic sharia principles. IDB was then formally established in August 1974 where Indonesia became one of the founding member countries. Several international Islamic banks have come to Indonesia to open sharia financial institutions jointly. This shows the amount of hope and support of international financial institutions for the existence of Islamic financial institutions in Indonesia.

- The provision of mudharabah loans with a profit sharing system is very suitable to the needs of the community because:

- Provision of mudharabah loans encourages the establishment of togetherness between shohibul maal and mudharib in dealing with business risks and dividing profits / losses fairly.

- In mudharabah loans, the customer is only required to share the results of his business in accordance with the agreement agreed upon at the beginning of the contract.

- In mudharabah loans does not depend on the high and low interest rates because there is no interest expense on loans that must be taken into account.

b) Weaknesses of the mudharabah system, namely:

- Prejudice to its customers and assume that all people involved in the production sharing agreement are honest and can backfire, because mudaraba loans with a profit sharing system will depend on honesty and goodwill from its customers as mudarib.

- Because it carries a profit sharing mission, the Shariah bank needs more reliable professionals in their fields.

- Requires complicated calculations, especially in calculating costs and profits from both parties.

c) Risks contained in mudharabah, especially in its application in financing are relatively high, including.

- Side streaming, the customer uses the funds not as stated in the contract

- Negligent and deliberate mistakes

- Concealment of profits by customers if the customer is dishonest.

Profit or loss recognition in practice can be known based on the profit sharing report from the fund manager received by the bank. In this case the loss incurred is recognized in the period of the loss and can reduce the mudharabah financing balance. 


\section{Results}

\subsection{Mudharabah Mutlaqah Between Theory and Practice}

In shari'ah banking practices in Indonesia, the principle fund collection products used are Mudharabah muthlaqah while Mudharabah muqayyadah is more often used in service products whose application to the Shari'ah Bank is a special investment product that is a project directly financed by the customer, the bank only acts as the representative who arranged the project.

Pass to the subject matter, which in this study the author discusses the mudharobah mutlaqah product between theory and practice at the Muamalat Bank Jambi Branch. that is:

a. In terms of theory

If in terms of theory, mudharabah mutlaqah (general investment), is a form of cooperation between shahibul mal and mudarib whose scope is very broad and not limited by the specifications of business type, time and business area. In the discussion of fiqh ulama, it is often exemplified by the expression if'al ma syi'ta (do as you please) from shahibul maal to mudharib which gives immense power.

Mudharabah mutlaqah can be defined as a cooperative agreement whereby shohibul maal gives full flexibility to mudharib to use the funds in a business that is considered good and lawful and profitable, but the manager is still responsible for managing according to practice. If the business experiences profits, it will be divided according to the agreed agreement and if the business experiences a loss, the loss will be borne by both parties.

This is in line with Profit Sharing, or the principle of profit sharing which is a general characteristic and basic foundation for the operation of Islamic banks as a whole. Syri'ah, the principle is based on the mudharbah rule.

\section{b. In terms of practice}

If in terms of practice, mudharabah mutlaqah is not synchronized with the theory, it can be seen from several complaints from customers who feel disadvantaged, namely:

- Syaiful Yahya

In this case, Mr. Syaiful Yahya used Mudharabah Mutlaqah product with member number 06.01.00714. Contract Number of Agreement 16 / MDA / VII / BMI / 2016. On 14-03-2016. For HP counter business, Rp. 18,000,000. Pembiayan Installment Account Card.

No. Member (NDA): 06.01.00714

Member Name: Syaiful Yahya

No. Agreement Agreement: 16 / MDA / VII / BMI / 2016

Tanngal: 14-03-2016

Types of Financing: Mudharabah Mutlaqah

Installment Method: Monthly

Disbursement Date: 03/14/2016

Duration: 10 months

Maturity: 01/14/2018

Guarantee: Land certificate

Amount of Financing: Rp. 18,000,000

Margin / Profit Sharing: IDR 540,000+

Total Financing: Rp. 18,540,000

Main Installment: Rp. 9,270,000

Margin / Profit Sharing: IDR 54,000 
Risk Reserves: IDR 434,000

Mandatory Deposits: IDR 434,000

Takaful Insurance: -

Infaq / Sadaqah: IDR 5,000

Total Installments: Rp 927,000

Amount of Financing: Rp. 18,000,000

- Amount of Margin / Profit Sharing: The amount of financing multiplied by $3 \%$ Rp. $18,000,000 \times x=$ Rp. 540,000

- Principal Installments: Total financing divided by 2 Rp. 18,540,000: 2 = Rp. 9,270,000

- Margin / Profit Sharing: The amount of margin / profit sharing divided by the length of the loan $=$ Rp. $540,000: 10=$ Rp. 54,000

- Infaq / Shadaqah: IDR 5,000

- Risk reserve: The principal installment for the length of the loan is reduced margin / profit sharing per month minus infaq / sadaqah divided by $2=$

Rp 9,270,000: 10 - 5 4,000 - 5,000: $2=$

IDR 434,000

- Mandatory Deposits: The principal installment for the duration of the loan is reduced margin / profit sharing per month minus infaq / sadaqah divided by $2=$ Rp 9,270,000: 10 - 5 4,000 - 5,000: 2 = Rp. 434,000

- Installment Total: Risk reserve plus mandatory savings plus margin / profit sharing per month plus infaq or sadaqah $=$ Rp. $434,000+434,000+54,000+5,000=$ Rp. 927,000

From the details of the financing of the mudharabah mutlaqah above, Mr. Syaiful Yahya must distribute the profits of his HP counter business to Bank Muamalat in the amount of Rp. 927,000 per month.

If Mr. Syaiful Yahya does not give profit to the bank, therefore, you have to pay Rp.1,854,000 for the late fees.

After confirmation in the field, the late payment of the profit sharing was because $\mathrm{Mr}$. Syaiful suffered a loss in his contingent business, it was because the income did not reach the expected target, not to mention the payment of other expenses which also had to be repaid.

- Siti Fatimah

In this case, Ibu Siti Fatimah, who lives in Thehok Beringin VII, South Jambi Subdistrict, also used Mudharabah Mutlaqah products with member number 06.01.00465. Contract Agreement Number 71 / MDA / XI / BMI / 2015. For the business of opening a Play Station rental (PS) of Rp. 14,750,000.

Installment Account Card

No. Member (NDA): 06.01.00465

Member Name: Siti Fathimah

No. Agreement Agreement: 71 / MDA / XI / BMI / 2015

Date: 12-04-2015

Types of Financing: Mudharabah Mutlaqah

Installment Method: Monthly

Disbursement Date: 12-04-2015

Duration: 10 months

Maturity: 12-02-2016 
Guarantee: Land certificate

Amount of Financing: Rp. 14,750,00

Margin / Profit Sharing: IDR 442,500

Total Financing: Rp. 15,192,500

Main Installments: Rp. 7,596,250

Margin / Profit Sharing: IDR 44,250

Risk Reserves: Rp. 355,187.5

Mandatory Deposits: Rp. 355,187.5

Takaful Insurance: -

Infaq / Sadaqah: IDR 5,000

Total Installments: Rp. 759,625

Amount of Financing: Rp. 14,750,000

- Amount of Margin / Profit Sharing: The amount of financing multiplied by $3 \%$ Rp. $14,750,000 \mathrm{x}=$ Rp. 442,500

- Principal Installments: Total financing divided by 2 = Rp. 15,192,500: 2 = Rp. 7,596,250

- Margin / Profit Sharing: Amount of Margin / Profit Sharing divided by length of loan = Rp. 442,500: $10=$ Rp. 44,250

- Infaq / Shadaqah: IDR 5,000

- Risk reserve: The principal installment for the length of the loan is reduced margin / profit sharing per month minus infaq / sadaqah divided by $2=$

Rp 7,596,250: 10 - 44,250 - 5,000: 2 = Rp. 355,187.5

- Mandatory Deposits: The principal installment for the length of the loan is reduced margin / profit sharing per month minus infaq / sadaqah divided by $2=$

Rp 7,596,250: 10 - 44,250 - 5,000: $2=$

Rp. $355,187.5$

- Total Installments: Risk Reserves plus mandatory savings plus margin / profit sharing per month plus infaq or sadaqah $=$ Rp. $355187.5+355187.5+44.250+5,000=$ Rp. 759,625

From the details of the financing of mudharabah mutlaqah above, Mrs. Siti Fatimah must share the benefits of the Play Station (PS) rental business to Bank Muamalat in the amount of Rp. 759,625 per month.

If Siti Fathimah's mother does not give a profit to the bank with a 3\% profit agreement, Ibu Siti Fathimah must pay Rp 1,519,250 for the cost of the delay.

After confirming to the play stationm rental place, Mrs. Siti Fatima, it turned out that I found out that the late payment of the profit sharing was because Fathimah had suffered a loss in the play station business, this was because this month the person playing play station was reduced, not as usual. Usually students who go home from school go directly to the play station and teenagers around Siti Fathimah's mother's neighborhood.

- Robbiyatul Adawiyah

In this case Mrs. Robbiyatul Adawiyah also used the Mudharabah Mutlaqah product with a member number 08.02.00889. Agreement Number 03 / MDA / XI / BMI / 2010. On 14-022010. For businesses opening a mobile counter rental of Rp. 15,000,000

Pembiayan Installment Account Card

No. Member (NDA): 08.02.00889

Member Name: Robbiyatul Adawiyah 
No. Agreement Agreement: 03 / MDA / XI / BMI / 2008

Date: 14-02-2008

Types of Financing: Mudharabah Mutlaqah

Installment Method: Monthly

Disbursement Date: 14-02-2010

Duration: 10 months

Maturity: 14-12-2010

Guarantee: Land Certificate

Amount of Financing: Rp. 15,000,000

Margin / Profit Sharing: IDR 450,000

Total Financing: Rp. 15,450,000

Principal Installments: IDR 7,725,000

Margin / Profit Sharing: IDR 45,000

Risk Reserves: Rp. 361,250

Mandatory Deposit: IDR 361,250

Takaful Insurance: -

Infaq / Sadaqah: IDR 5,000

Total Installments: Rp. 772,500

Amount of Financing: Rp. 15,000,00

- Amount of Margin / Profit Sharing: The amount of financing multiplied by 3\% IDR $15,000,000 \mathrm{x}=$ IDR 450,000

- Principal Installments: Total financing divided by $2=$ IDR 15,450,000: $2=$ IDR 7,725,000

- Margin / Profit Sharing: Amount of Margin / Profit Sharing divided by length of loan = IDR 450,000: $10=$ IDR 45,000

- Infaq / Shadaqah: IDR 5,000

- Risk reserve: The principal installment for the length of the loan is reduced margin / profit sharing per month minus infaq / sadaqah divided by $2=$

Rp 7,725,000: 10 - 45,000 - 5,000: $2=$

Rp. 361,250

- Mandatory Deposits: The principal installment for the length of the loan is reduced margin / profit sharing per month minus infaq / sadaqah divided by $2=$

Rp 7,725,000: 10 - 45,000 - 5,000: 2 =

Rp. 361,250

- Total Installments: Risk Reserves plus mandatory savings plus margin / profit sharing per month plus infaq or sadaqah $=$ Rp. $361,250+361,250+45,000+5,000=$ Rp. 772,500

Mrs. Robbiyatul Adawiyah did not provide benefits to the bank with a 3\% profit agreement, therefore on July 14, 2010, Mrs. Robbiyatul Adawiyah had to pay Rp 1,545,000 for the late fees.

After confirming to Robbiyatul Adawiyah's cellphone counter, I found out that the late payment of the profit sharing was due to a loss in running the business on June 14, 2010. The loss was due to competition between other cellphone counters. Mrs. Robiyatul Adawiyah pays more than in previous months, therefore mother Robiyatul Adawiyah borrows money from her siblings to pay off the payment every month if she experiences a loss or failure to reach the monthly income level after deducting expenses or other expenses. 


\section{Conclusions}

- If viewed from the aspect of the mudharabah mutlaqah theory, it can be defined as a cooperative contract whereby shohibul maal gives full flexibility to mudarib to use the fund in a business that is considered good and lawful and profitable, but the manager is still responsible for managing according to practice. If the business experiences profits, it will be divided according to the agreed agreement and if the business experiences a loss, the loss will be borne by both parties.

- In terms of practice, mudharabah mutlaqah is not synchronized with the theory, it can be seen from several complaints from the customer, if the mudarib business experiences profits will be divided according to the agreed agreement but if the business experiences a loss, then the loss will borne by mudharib as manager.

- From the problem of mudaraba mutlaqah the study between theory and practice, that the occurrence of these problems is due to the communication between Shohibul Maal and the Mudharib party. As well as a lack of understanding of mudharib in mudharabah mutlaqah products.

- The challenge of Bank Muamalat in addressing these problems, that the risks in mudharabah mutlaqah products, especially in the implementation of its financing are relatively high, have good prejudice for all its customers and assume that all people involved in this agreement are honest can be a boomerang for the bank, and require skilled professionals in their fields.

- Constraints faced by Bank Muamalat in developing its products in the event of an incompatibility between sharia rules and the reality that occurs in the field, namely between theory and practice. And the mudharabah mutlaqah products offered by the bank include high risk products. In this product the bank not only imposes risk on the customer, and in practice the bank cannot take the risk too high, therefore this mudharabah mutlaqah financing product is only given to customers who have 5C (Character, Career, Capital, Credibility, Capabelity) to suppress the risk is too high.

- The policy adopted by Muamalat bank in addressing the problem of mudharabah mutlaqah, namely offering this product to customers who have $5 \mathrm{C}$, and the bank must have the principle of prudence and be more selective in developing its products.

\section{References}

[1] Antonio, M. S. (2010) Bank Syariah Dari Teori ke Praktek. Jakarta: Gema Insani.

[2] Atmaja, L. S. (2008) Teori dan Praktik Manajemen Keuangan. Yogyakarta: Andi. 